\title{
Self-replacement and community modification by the southern bull kelp Durvillaea antarctica
}

\author{
David I. Taylor*, David R. Schiel \\ Marine Ecology Research Group, School of Biological Sciences, University of Canterbury, Private Bag 4800, \\ Christchurch 1, New Zealand
}

\begin{abstract}
Stands of the southern bull kelp Durvillaea antarctica (Chamisso) Hariot provide considerable biomass and a major habitat in the lower intertidal zone of exposed shores on the austral land masses. Whiplash effects of adult fronds (up to $10 \mathrm{~m}$ long) can affect recruitment, growth and survival of understorey species and potentially large brown algal competitors, thereby affecting community development. In southern New Zealand, D. antarctica is one of several species of large brown algae inhabiting the low intertidal zone. Effects of its canopy and its associated understorey coralline algae on community development were tested at 2 sites (Moeraki and Kaikoura) at different times of year between February 1999 and October 2001. Removal of D. antarctica canopies had surprising results compared to most studies where canopies of large brown algae were removed. The greatest initial recruitment of bull kelp occurred beneath intact canopies, usually in areas where corallines were removed. Recruitment was highly variable through time, with peaks occurring in June and October (austral winter-spring), depending mostly on when canopies were removed. There was an order of magnitude difference in recruitment between sites. The cover of turfing coralline algae, however, increased in all canopy removal treatments. A major source of mortality of young recruits was grazing by the herbivorous fish Odax pullus. Its distinct grazing marks were seen on recruits, almost exclusively outside the canopy of bull kelp where $80 \%$ of recruits were grazed. We show that $D$. antarctica has the ability to recruit beneath adult canopies, but that survival and growth ultimately depend on the extent of canopies, underlaying benthic algae and escapes from grazing by herbivorous fish.
\end{abstract}

KEY WORDS: Durvillaea antarctica · Recruitment · Intertidal algae · Substratum · Canopy · Fish grazing Resale or republication not permitted without written consent of the publisher

\section{INTRODUCTION}

Large brown algae dominate many marine rocky shores world-wide, providing biomass, food and biogenic habitat that support most inshore species. Although many species of algae, particularly those of the order Fucales, are desiccation-resistant and occur throughout the intertidal zone, the large and dense stands usually begin along the intertidal-subtidal fringe (Stephenson \& Stephenson 1972). Here, aerial exposure occurs only during the lowest of tides, but on high-energy shores, wave splash ameliorates this effect. As few of the species that occur at this fringe can survive either higher in the intertidal zone (cf.
Schonbeck \& Norton 1978) or lower in the subtidal zone (cf. Choat \& Schiel 1982, Chapman 1995), this habitat is likely to be unique in the combination of processes that structure and maintain it. If this is the case, general models accounting for community structure (Menge et al. 1997) will require modification. Furthermore, a general understanding of structuring processes must include regional or global differences in the important taxa (Menge \& Branch 2001).

One of the largest species of algae in the southern hemisphere occurs at the intertidal-subtidal fringe of exposed shores. The southern bull kelp Durvillaea antarctica (Chamisso) Hariot is abundant on most southern land masses at latitudes between 45 and 
$60^{\circ} \mathrm{S}$ including Tasmania, Chile, New Zealand and the sub-antarctic islands (Hay \& South 1979, Santelices et al. 1980, Santelices 1990a). This species is the largest member of the order Fucales (Hurd 2000) and is surpassed in size only by a few of the largest laminarian algae. Fronds of this species can reach $10 \mathrm{~m}$ in length, while their biomass reaches up to $80 \mathrm{~kg} \mathrm{~m}^{-2}$ (Santelices et al. 1980, D.R.S. unpubl. data). Its positive effects on communities include the provision of habitat for grazing invertebrates that reside in and around hold fasts of adult plants (Hay 1977, Santelices 1990a, Edgar \& Burton 2000). For example, Edgar \& Burton (2000) found 23 macro-invertebrate taxa associated with $D$. antarctica holdfasts on the subantarctic Heard Island. However, D. antarctica can also reduce or eliminate other species through the whiplash effects of its fronds (Santelices et al. 1980), leaving only a few species of tough foliose and coralline algae intact near canopies of $D$. antarctica.

Unlike Chile, however, where most of the potentially competing species are laminarian algae, particularly the tough Lessonia nigrescens (Santelices et al. 1980, Santelices \& Ojeda 1984, Santelices 1990a), southern New Zealand has a rich flora of fucalean species as well as a wide variety of red algae in the lowest intertidal zone (Naylor 1953, Hay 1977, Schiel 1990, Nelson 1994, Schiel et al. 1995). Durvillaea antarctica occurs almost exclusively at exposed, outer coast sites, occasionally intruding into semi-exposed areas (such as behind headlands), but never into sheltered areas (Santelices 1990a, Taylor \& Schiel 2003). There are usually few other foliose algae present, except hardy turfing coralline and other red algae, in the vicinity of adult bull kelp. Recruitment can be extensive. In southern New Zealand, Hay \& South (1981) found that dense recruitment occurred in patches where plants were removed. This tended to be seasonal because in southern New Zealand, D. antarctica reproduces during austral autumn and winter (April to September) (Hay 1977) and greatest recruitment occurs during late winter-early spring.

Algal canopies can affect spore dispersal, light and nutrient supply to areas below, and the whiplash of fronds and the extensive areas occupied by holdfasts can pre-empt successful recruitment (Kennelly 1983, Dayton et al. 1984, Santelices \& Ojeda 1984, Schiel \& Foster 1986, Foster \& Schiel 1987, Schiel 1988, 1990, Santelices 1990b, Connell 2003a). Consequently, large brown algae often recruit poorly beneath adult canopies compared to gaps outside them. For example, Santelices \& Ojeda (1984) found that canopy effects and grazing combined to inhibit recruitment of Lessonia nigrescens Bory in central Chile. For multi-species assemblages, however, much of our understanding of the effects of large brown algae canopies comes from subtidal studies. For example, Dayton et al. (1984) followed demographic patterns of populations in southern California over a $10 \mathrm{yr}$ period, removed canopies and seeded areas with sporogenic material of several algal species. They found a dominance hierarchy for light competition determined by adult canopy height, but a trade-off in the ability of higher canopies to withstand wave stresses. Of overriding importance, however, were the life-history constraints such as dispersal abilities and growth rates that determined the ability of each species to invade and persist under canopies of other algal species.

The relationship between recruitment of large brown algae and the corallines that occur beneath them is unclear. Coralline algae, a common feature of the understorey in lower intertidal and subtidal habitats, have been found both to inhibit the recruitment of some species and facilitate others (Connell 2003a,b). For example, Camus (1994) suggested that encrusting coralline algae reduced recruitment of Lessonia nigrescens in northern Chile by shedding epithallial cells. In other studies, turfing corallines facilitated recruitment of fucoid algae by providing suitable micro-habitat conditions (Brawley \& Johnson 1991, 1993, Benedetti-Cecchi \& Cinelli 1992).

Here, we seek to elucidate the structuring processes in one of the most dominant and extensive assemblages in southern New Zealand (Nelson 1994). We test the effects of Durvillaea antarctica canopies, understorey corallines and the influence of different timing of disturbances on algal community development. These are then discussed with reference to the prevailing understanding of these processes in other related assemblages.

\section{MATERIALS AND METHODS}

Study sites. Two algal-covered platforms on the central eastern coast of South Island of New Zealand were used. First Bay, located on the NE end of the Kaikoura site $\left(42^{\circ} 25^{\prime} \mathrm{S}, 173^{\circ} 44^{\prime} \mathrm{E}\right)$, is a mudstone platform that extends $70 \mathrm{~m}$ from the land. At its eroded edge are small fragments of harder reef covered in Durvillaea antarctica (Hay 1979). Waves are rarely less than $1 \mathrm{~m}$ in height and oceanic swells hit the reef largely unimpeded. The other study site was a platform of volcanic rock on the northern end of Moeraki $\left(45^{\circ} 11^{\prime} \mathrm{S}\right.$, $170^{\circ} 98^{\prime} \mathrm{E}, 400 \mathrm{~km}$ south of Kaikoura). It is around $200 \mathrm{~m}$ long and $60 \mathrm{~m}$ wide. It has large beds of D. antarctica on flat but broken reef along its seaward margin, which is exposed to oceanic swells. At both sites, D. antarctica occurs at the 0.1 to $0.25 \mathrm{~m}$ tidal level. Both sites are further described in Schiel \& Taylor (1999). 
The understorey at both sites is dominated by a complex of turfing and encrusting coralline algae, especially Haloptilon roseum (Lamarck) Garbary et Johansen, Jania micrarthrodia JV Lamouroux, Corallina officinalis Linnaeus and Lithothamnion spp., which together covered over $95 \%$ of the primary stubstrata at both sites (Table 1). Bare substratum was scarce $(<5 \%)$, usually occurring in any abundance only where adult holdfasts had detached.

Experimental design. The intertidal-subtidal fringe of exposed shores is notoriously difficult to work in. It is only fully emerged on the lowest tides, but swell conditions can limit access and the ability to do some types of manipulative experiments. For example, we trialled several types of cages and fences to test grazing effects of gastropods, but all devices were pummelled and destroyed, usually within a month, by waves and the fronds of Durvillaea antarctica. Our experiments were, therefore, limited to canopy and substratum manipulations.

To test the effects of canopies and coralline algae on recruitment, 3 fully crossed factors were used: sites (n $=2$, treated as random), canopies $(+/-$; fixed) and coralline algae $(+/-$; fixed). Plots $(30 \times 30 \mathrm{~cm})$ were marked under a canopy or in areas where canopies had been cleared, and randomly assigned as plus or minus coralline algae. Plots were marked with a plastic anchor plug. The coralline algae removal treatments were scraped back to bare rock using a tile hammer. To ensure that there were no 'whiplash' effects of the Durvillaea antarctica canopy in the clearance plots, canopies were removed for several metres away from adult plants so that none of the adult fronds were able to reach the clearance treatment plots. There were 4 replicates of each treatment

We tested the effect of disturbance at different times, by initiating the full design 5 times: in summer (January 1999), autumn (May 1999), winter (August 1999), spring (October 1999) and the following summer (Jan-

Table 1. Percentage cover (mean, SE) and abundance data (mean per $0.09 \mathrm{~m}^{2}$ ) for dominant species and functional groups in all treatments at Moeraki and Kaikoura before treatment initiation. Data are averages from all clearance times

\begin{tabular}{|llcc|}
\hline Unit & At Day 0 & Moeraki & Kaikoura \\
\hline$\%$ & All turfing corallines & $40.8(6.10)$ & $10.2(1.73)$ \\
$\%$ & Jania spp. & $32.6(4.88)$ & $1.3(0.24)$ \\
$\%$ & Haliptilon roseum & $6.5(1.46)$ & $6.9(1.23)$ \\
$\%$ & All encrusting corallines & $57.0(6.09)$ & $85.1(1.61)$ \\
$\%$ & Other foliose algae & $7.9(1.80)$ & $5.8(1.34)$ \\
$\%$ & Bare substratum & $1.6(0.34)$ & $4.2(0.72)$ \\
$\%$ & Durvillaea antarctica canopy & $100.0(0.05)$ & $99.8(0.09)$ \\
$\%$ & Durvillaea antarctica recruits & $2.2(0.79)$ & $1.5(0.47)$ \\
$\#$ & Durvillaea antarctica & $2.1(0.83)$ & $1.1(0.66)$ \\
$\#$ & Molluscan grazers & $1.5(0.42)$ & $1.5(0.29)$ \\
\hline
\end{tabular}

uary 2000). As the design was pre-planned, we were able to randomise all treatments through time and as these experiments were placed into the lowest tidal zone on exposed shores, monitoring had to be performed opportunistically when swell and tide conditions permitted. This was done prior to the experiment and then 5 times between May 1999 and October 2001. The first 4 sampling times were 5 to 7 mo apart. The last sample (October 2001) was to determine the result of the matured experimental treatments.

Treatments were monitored using a $30 \times 30 \mathrm{~cm}$ quadrat divided into 100 equally sized squares. Each treatment was visually assessed for the percentage cover of large brown algae, other foliose algae, encrusting coralline algae, turfing coralline algae, and bare rock. Invertebrate herbivores and large brown algal recruits were counted. In March and October 2001, the total length (base of holdfast to tip of blade) of each surviving Durvillaea antarctica recruit was measured. The number of recruits with lunate grazing marks was also recorded.

Data analysis. Analysis of variance models were used to test for treatment effects on the number and percentage cover of new Durvillaea antarctica recruits at 4 sampling periods. Analysis of variance models were also used to test for treatment effects on the percentage cover of turfing coralline algae, encrusting coralline algae and all other foliose algae at the end of the experiment in October 2001. The main factors were Site (random), Season cleared (summer 1998/99, autumn 1999, winter 1999, spring 1999, summer 1999/2000, fixed), Canopy (+/-, fixed) and Substratum (+/- coralline algae, fixed). Data were tested for homogeneity of variances using Cochran's test prior to analysis. If significant, data were square-root-transformed, arcsine-transformed or log-transformed (log $[n+1])$ prior to analysis. Where appropriate, Tukey HSD tests were used to locate differences among treatments following univariate analyses. Data were analysed in Statistica $5^{\circledR}$ (StatSoft).

\section{RESULTS}

\section{Recruitment of Durvillaea antarctica}

Recruitment was highly variable across sites, treatments and sampling times (Table 2, Fig. 1). The summer 1998/99 treatments had far greater recruitment in Moeraki than in Kaikoura through the first 3 samples (Fig. 1A,F), and for most sampling times, the magnitude of treatment effects differed between sites (Table 2). On the last sampling date (October 2001), the most recruits appeared in Kaikoura in the treatment where the canopy and substratum were removed. The treat- 
Table 2. Durvillaea antarctica. Summary of ANOVA of the total number of new recruits with Site, Season cleared (Sn), Canopy (Can) and Substratum (Sub) as factors. Significance levels: ${ }^{*} p=0.05 ;{ }^{* *} p=0.01 ;{ }^{* * *} p=0.001$. Data were (a) log (n+1) or (b) square-root-transformed. Bold indicates significant effects. Cochran's tests were not significant

\begin{tabular}{|c|c|c|c|c|c|c|c|c|c|c|c|c|}
\hline \multirow[t]{2}{*}{ Source } & \multicolumn{3}{|c|}{ October $1999^{\mathrm{a}}$} & \multicolumn{3}{|c|}{ June $2000^{\mathrm{a}}$} & \multicolumn{3}{|c|}{ March/April 2001 a } & \multicolumn{3}{|c|}{ October $2001^{\mathrm{b}}$} \\
\hline & df & MS & $F$ & df & MS & $F$ & $\mathrm{df}$ & MS & $F$ & $\mathrm{df}$ & MS & $F$ \\
\hline Site & 1 & 22.62 & $19.64^{* * *}$ & 1 & 43.91 & $85.57^{* * *}$ & 1 & 4.81 & $4.67^{*}$ & 1 & 28.85 & $25.24^{* * *}$ \\
\hline Season cleared & 3 & 13.70 & 3.12 & 4 & 6.68 & 1.73 & 4 & 11.08 & $7.81^{*}$ & 4 & 10.95 & 6.56 \\
\hline Canopy & 1 & 0.08 & 0.04 & 1 & 0.32 & 0.04 & 1 & 0.00 & 0.00 & 1 & 0.02 & 0.00 \\
\hline Substratum & 1 & 22.11 & 7.81 & 1 & 8.25 & 0.83 & 1 & 13.47 & 2.74 & 1 & 22.97 & 14.56 \\
\hline Site $\times$ Sn & 3 & 4.39 & $3.81^{*}$ & 4 & 3.85 & $7.51^{* * *}$ & 4 & 1.42 & 1.38 & 4 & 1.67 & 1.46 \\
\hline Site $\times$ Can & 1 & 1.96 & 1.70 & 1 & 7.94 & $15.47^{* * *}$ & 1 & 33.84 & $32.87^{* * *}$ & 1 & 11.61 & $10.16^{* *}$ \\
\hline $\mathrm{Sn} \times \mathrm{Can}$ & 3 & 4.56 & 0.82 & 4 & 2.00 & 2.06 & 4 & 4.32 & $4.83^{*}$ & 4 & 2.09 & 1.59 \\
\hline Site $\times$ Sub & 1 & 2.83 & 2.46 & 1 & 9.88 & $19.25^{* * *}$ & 1 & 4.92 & $4.78^{*}$ & 1 & 1.58 & 1.38 \\
\hline $\mathrm{Sn} \times \mathrm{Sub}$ & 3 & 13.20 & 2.51 & 4 & 5.28 & 0.93 & 4 & 5.80 & 4.05 & 4 & 3.41 & 3.58 \\
\hline Can $\times$ Sub & 1 & 6.37 & 0.81 & 1 & 14.23 & 1.93 & 1 & 0.64 & 17.88 & 1 & 4.61 & 1.47 \\
\hline Site $\times \mathrm{Sn} \times$ Can & 3 & 5.59 & $4.85^{* *}$ & 4 & 0.97 & 1.90 & 4 & 0.89 & 0.87 & 4 & 1.32 & 1.15 \\
\hline Site $\times \mathrm{Sn} \times \mathrm{Sub}$ & 3 & 5.26 & $4.56^{* *}$ & 4 & 5.67 & $11.04^{* * *}$ & 4 & 1.43 & 1.39 & 4 & 0.95 & 0.83 \\
\hline Site $\times$ Can $\times$ Sub & 1 & 7.88 & $6.84^{*}$ & 1 & 7.37 & $14.37^{* * *}$ & 1 & 0.04 & 0.03 & 1 & 3.14 & 2.75 \\
\hline $\mathrm{Sn} \times \mathrm{Can} \times \mathrm{Sub}$ & 3 & 3.15 & 2.81 & 4 & 2.82 & 1.06 & 4 & 1.98 & $20.95^{* *}$ & 4 & 1.14 & 0.66 \\
\hline $\begin{array}{l}\text { Site } \times \text { Sn } \times \\
\text { Can } \times \text { Sub }\end{array}$ & 3 & 1.12 & 0.98 & 4 & 2.67 & $5.20^{* * *}$ & 4 & 0.09 & 0.09 & 4 & 1.73 & 1.51 \\
\hline Error & & 96 & 1.15 & & 120 & 0.51 & & 120 & 1.03 & & 120 & 1.14 \\
\hline
\end{tabular}

ments initiated in autumn 1999 also recruited greatly by the following spring (October 1999) and mostly at Moeraki. There were significant Site $\times$ Season of clearance and Site $\times$ Canopy interactions for most sampling periods, but these often depended on the season of clearance. Most recruits appeared in the +Canopy -Substratum treatments at Moeraki but in the -Can -Sub treatment in Kaikoura. As for the Summer 1998/99 treatments, about $6 \times$ as many recruits appeared at Moeraki than at Kaikoura. The treatments initiated in winter 1999 did not recruit well until the following winter (June 2000) (Fig. 1C,H). Again, most recruits appeared in Moeraki, in treatments where the canopy was intact but the underlying substratum algae were removed. Treatments initiated in spring 1999 had low-level recruitment the following winter at Moeraki and did not recruit until the following year in Kaikoura (Fig. 1D,I). The treatments initiated in summer 1999/ 2000 had recruitment during the following $2 \mathrm{yr}$ but it was highly variable among all factors and there were no significant effects.

Overall, recruitment of Durvillaea occurred sooner at Moeraki than at Kaikoura. Almost invariably, the poorest recruitment occurred in Controls (+Can +Sub) and, overall, the greatest number of recruits appeared beneath an intact canopy where the substratum had been cleared.

\section{Total recruitment}

Over the entire experiment, the cumulative recruitment of Durvillaea gave an overall indication of treat- ment effects and showed significant Site $\times$ Canopy $\left(F_{1,120}=21.47, \mathrm{p}<0.001\right)$ and Site $\times$ Clearance time $\left(F_{4,120}=2.51, \mathrm{p}=0.046\right)$ interactions (Fig. 2$)$. The greatest total recruitment occurred at Moeraki in the Summer 1998/99, autumn and winter clearances, mostly where the adult canopy remained intact. At Kaikoura, the greatest total recruitment was in the winter clearances where the canopy had been removed. Substratum alone also had a significant effect on recruitment $\left(F_{1,1}=577.60, \mathrm{p}=0.03\right)$; over all other treatments, there was an average of $73( \pm 12)$ Durvillaea recruits where substratum coralline algae were removed but only 17 $( \pm 2)$ where the substratum remained intact.

\section{Percent cover of Durvillaea recruits}

The percent cover of recruits within treatments was highly variable (Fig. 3) and was affected by the variation in plant length (Fig. 4B). It generally mirrored recruitment patterns at Moeraki but not at Kaikoura where grazing had a greater effect on plant cover. The cover was greater in treatments where the substratum algae were removed at Moeraki, regardless of canopy presence or absence (Fig. 3A-E). The cover of recruits at Kaikoura was more variable and was often initially greater in canopy removal treatments (Fig. 3F-J). In several cases, the cover of recruits in the -Can treatments peaked and then declined or did not increase (Fig. 3B,D,E,G). This was because recruits were often grazed, leaving only the holdfast and a short stipe. At the end of the experiment, the cover of Durvillaea 
Moeraki
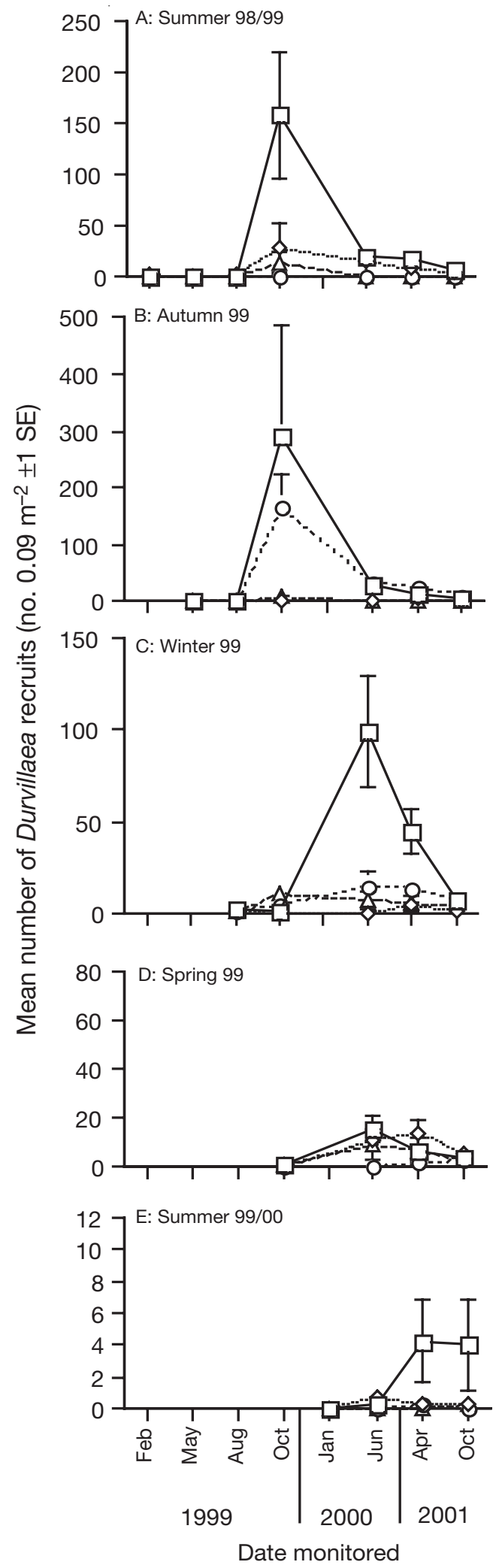

Kaikoura
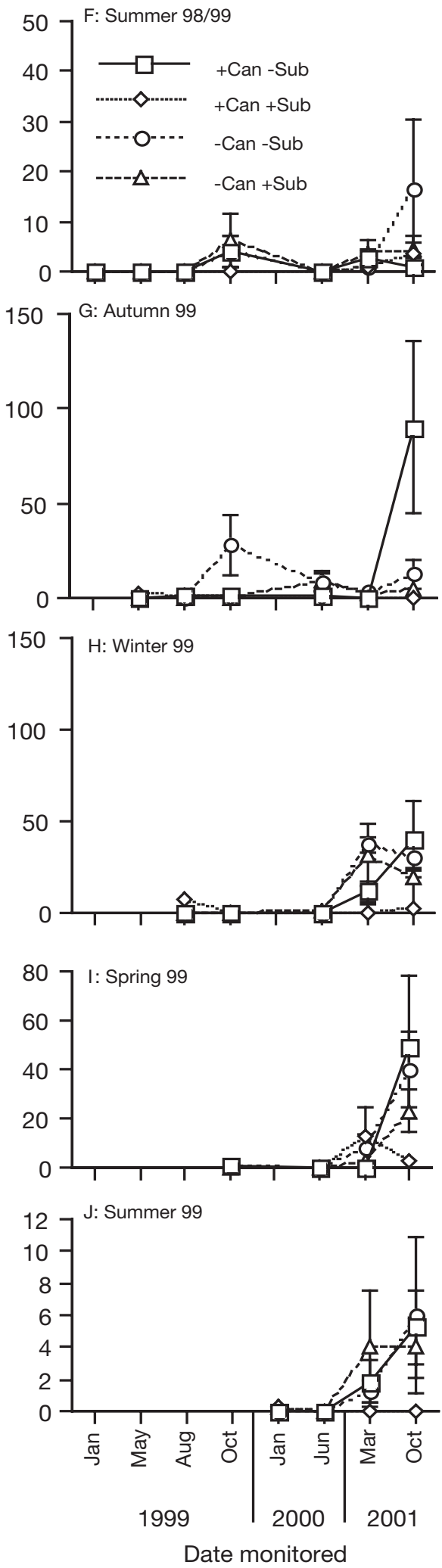

Fig. 1. Durvillaea antarctica. Mean number of newly appearing recruits per $0.09 \mathrm{~m}^{2}( \pm 1 \mathrm{SE})$ at each sampling time in the 5 initiation times in summer $1998(\mathrm{~A}, \mathrm{~F})$, autumn $1999(\mathrm{~B}, \mathrm{G})$, winter $1999(\mathrm{C}, \mathrm{H})$, spring 1999 (D,I) and summer 1999 (E,J) at Moeraki and Kaikoura. Treatments are canopy intact/removed (+Can/-Can) and understorey coralline algae intact/removed (+Sub/-Sub) 


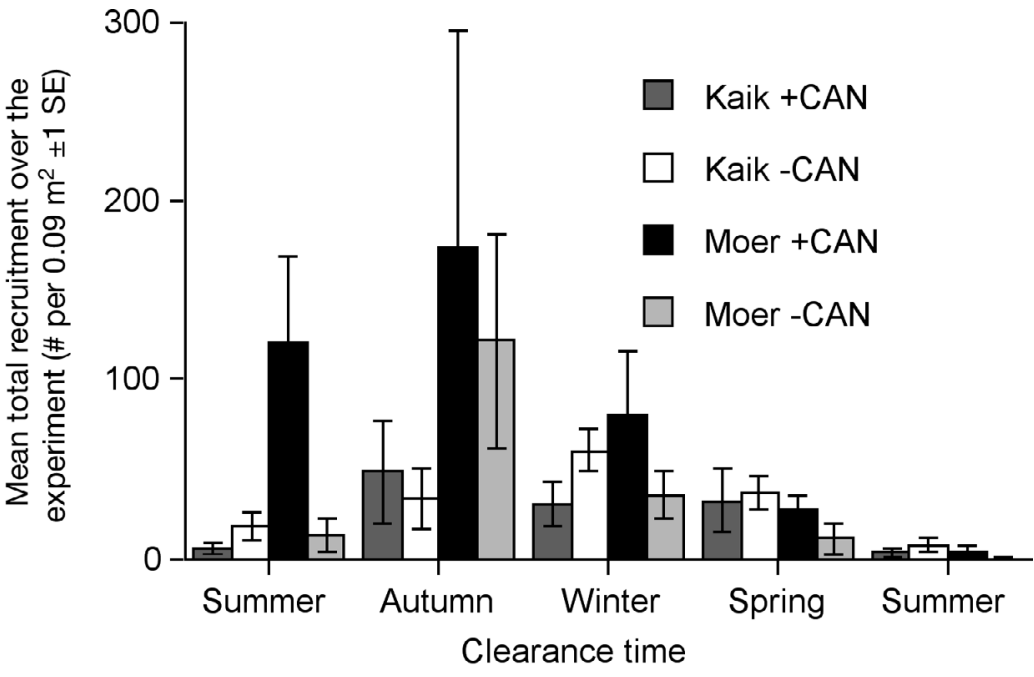

Fig. 2. Durvillaea antarctica. Mean total recruits per $0.09 \mathrm{~m}^{2}$ in all canopy-intact and canopy-removal treatments at Kaikoura and Moeraki at each of the 5 clearance times in October 2001

recruits was minimal in the spring 1999 and summer 1999/2000 treatments, and resulted in a significant effect of season of clearance (Table 3 ). There was also a significant Site $\times$ Canopy interaction effect. There did not appear to be much difference within similar treatments across clearance dates at Moeraki, with the greatest cover in the +Can -Sub treatments. However, at Kaikoura the single treatment with high cover was -Can + Sub. A significant Site $\times$ Substratum interaction effect was due to greater cover in the -Sub treatments

Table 3. Durvillaea antarctica. ANOVA results for percent cover of all recruits that survived to October 2001 with Site, Season (Sn), Canopy (Can) and Substratum (Sub) as factors. Significance levels: ${ }^{*} p=0.05 ;{ }^{* *} p=0.01 ;{ }^{* * *} p=0.001$. Data were square-root-transformed. Bold indicates significant effects. Cochran's tests were not significant

\begin{tabular}{|lccc|}
\hline Source & df & MS & $F$ \\
\hline Site & 1 & 0.32 & 0.04 \\
Season cleared & 4 & 88.07 & $\mathbf{8 . 7 8}^{*}$ \\
Canopy & 1 & 0.15 & 0.00 \\
Substratum & 1 & 99.60 & 3.39 \\
Site $\times$ Sn & 4 & 10.03 & 1.37 \\
Site $\times$ Can & 1 & 154.24 & $\mathbf{2 1 . 1 1 ^ { * * * }}$ \\
Sn $\times$ Can & 4 & 33.54 & 4.49 \\
Site $\times$ Sub & 1 & 29.39 & $\mathbf{4 . 0 2}$ \\
Sn $\times$ Sub & 4 & 28.04 & 2.08 \\
Can $\times$ Sub & 1 & 24.62 & 33.02 \\
Site $\times$ Sn $\times$ Can & 4 & 7.47 & 1.02 \\
Site $\times$ Sn $\times$ Sub & 4 & 13.51 & 1.85 \\
Site $\times$ Can $\times$ Sub & 1 & 0.75 & 0.10 \\
Sn $\times$ Can $\times$ Sub & 4 & 10.30 & 1.36 \\
Site $\times$ Sn $\times$ Can $\times$ Sub & 4 & 7.60 & 1.04 \\
Error & & 120 & 7.31 \\
& & & \\
\hline
\end{tabular}

at Moeraki. Overall, the quickest recovery occurred in the autumn and spring clearances at Moeraki. Summer clearances either did not recover (Fig. 3E,F,J) or took around 2 yr to reach 60 to $90 \%$ cover.

When results at the end of the experiment were pooled across all clearance times, there were 2 significant treatment effects (Fig. 4A). The greatest \% cover overall occurred in the clearances performed during winter, when Durvillaea was reproductive $\left(F_{4,4}=12.8, \mathrm{p}=0.015\right)$. These winter recruits covered up to $50 \%$ of the substratum in October 2001, while none of the other treatments had more than $30 \%$ cover of recruits. There was also a Site $\times$ Canopy interaction $\left(F_{1,119}=23.99, \mathrm{p}<0.001\right)$. Recruit plants had a greater cover outside of adult canopies at Kaikoura but beneath canopies at Moeraki (Fig. 4A). The percent cover of recruits mirrored the patterns for plant length (Fig. 4B).

\section{Durvillaea lengths}

At the end of the experiment, there were 2 significant treatment interactions involving the lengths of Durvillaea recruits. The highest order effect was the interaction of clearance times, substratum and canopies $\left(F_{4,4}=6.68, \mathrm{p}=0.046\right)$. Over these factors, plants tended to be largest under adult canopies where substratum coralline algae had been initially removed (Fig. 5). Pooled data across sites showed that plants in the -Sub +Can treatments averaged from 300 to $380 \mathrm{~mm}$ in length in the summer 1998/99 and autumn clearances, while plants in the +Sub +Can treatments were longest in the spring clearances (Fig. 5). In canopy removal treatments, plants in the Autumn and winter treatments averaged between 100 and $320 \mathrm{~mm}$. Overall, plants in the winter -Sub-Can treatments were significantly longer than the same treatments started in summer 1998/99, and summer 2000 treatments (Fig. 5; Tukey HSD, p < 0.05). There was also a significant Site $\times$ Canopy interaction $\left(F_{1,119}=27.98, \mathrm{p}<\right.$ 0.001). Plants at Kaikoura were longer outside of canopies, while those at Moeraki were longer beneath canopies (Fig. 4B; Tukey HSD, p < 0.05).

One of the greatest sources of mortality of developing Durvillaea recruits was grazing by what was later identified as the butterfish Odax pullus. Grazed plants had distinct lunate bites, which are characteristic of this herbivorous fish. Usually, most of the lamina was grazed, leaving only the stipe. Grazing was particularly evident where adult canopies had been removed (Fig. 4C). At Kaikoura, 60\% of -Can recruits were 
Moeraki
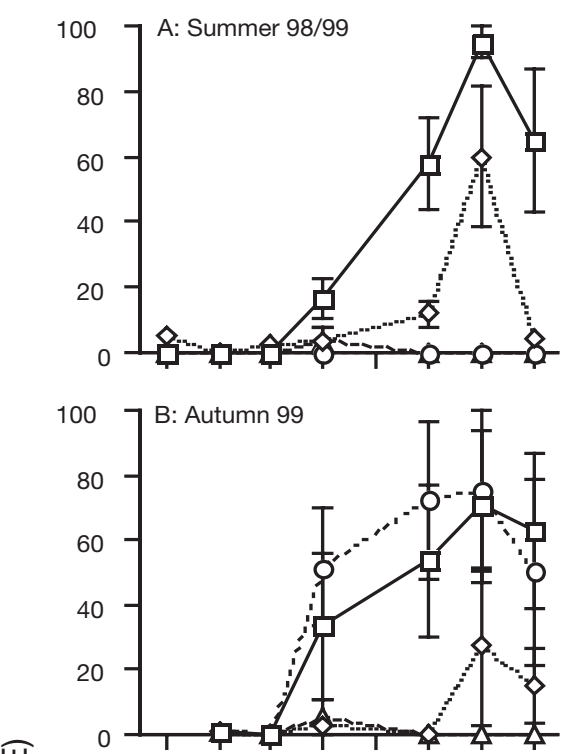

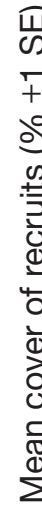
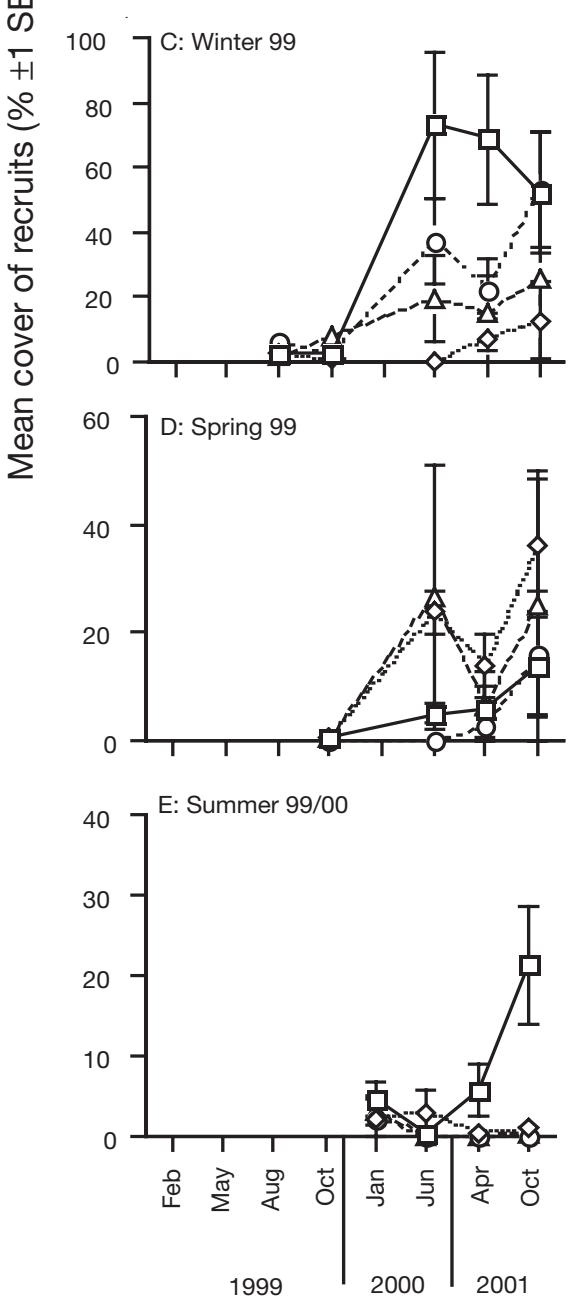

Date monitored
Kaikoura
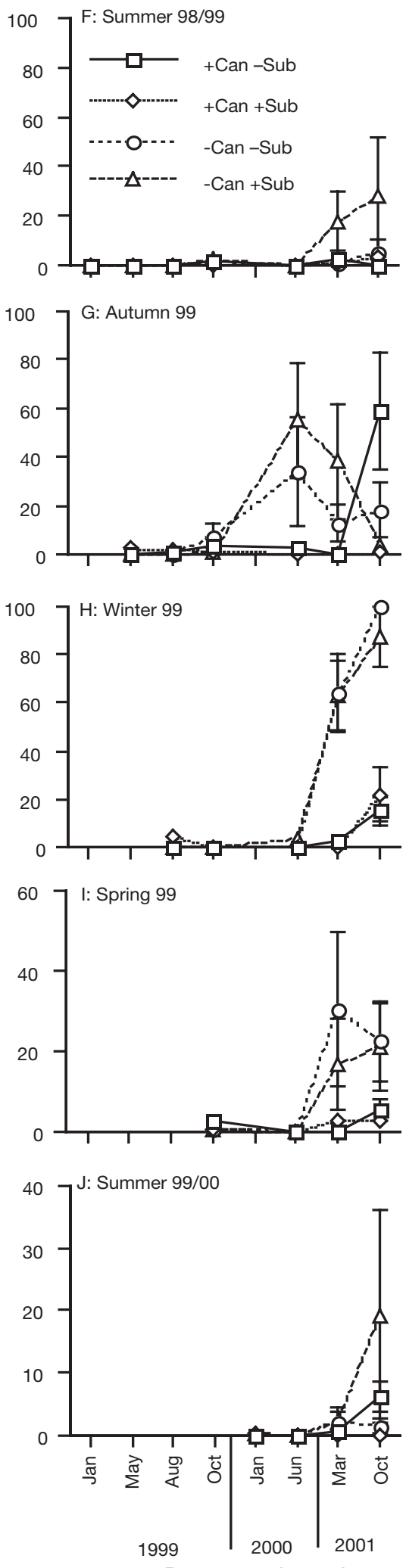

Date monitored

Fig. 3. Durvillaea antarctica. Mean percent cover $( \pm 1 \mathrm{SE})$ of recruits at each sampling time at the 5 initiation times in summer $1998(\mathrm{~A}, \mathrm{~F})$, autumn $1999(\mathrm{~B}, \mathrm{G})$, winter $1999(\mathrm{C}, \mathrm{H})$, spring $1999(\mathrm{D}, \mathrm{I})$ and summer 1999 (E,J) at Moeraki and Kaikoura 

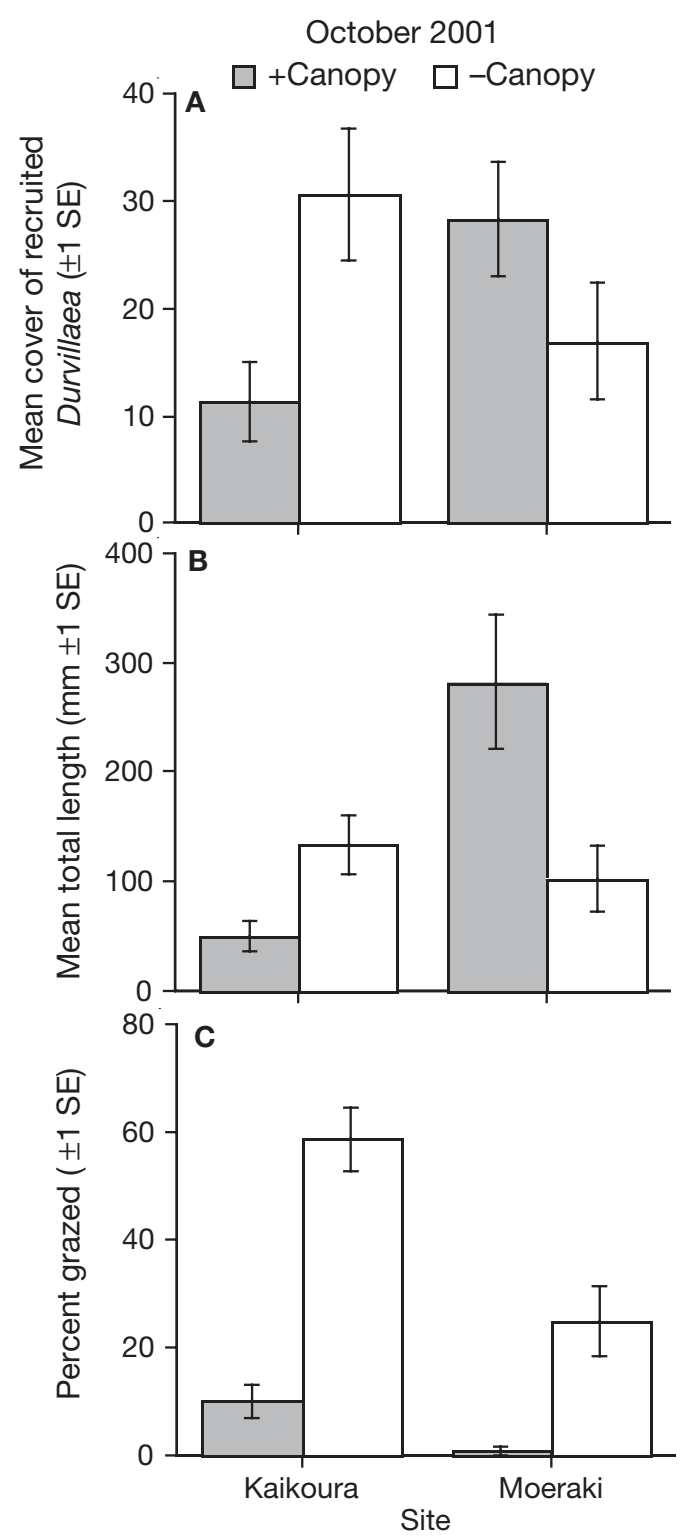

Fig. 4. Durvillaea antarctica. (A) Mean percent cover, (B) total length and $(\mathrm{C})$ percent grazed by the butterfish Odax pullus for recruits $( \pm 1 \mathrm{SE})$ in canopy intact treatments and canopy removal treatments at Moeraki and Kaikoura in October 2001

grazed but only $28 \%$ at Moeraki. However, the grazing effect was relatively stronger at Moeraki. Up to $28 \times$ more plants were grazed outside than under canopies at Moeraki, but only $6 \times$ as many in Kaikoura.

\section{Understorey foliose algae}

Only a few recruits of other fucalean algae (Carpophyllum maschalocarpum, Cystophora torulosa, Hormosira banksii, Xiphophora chondrophylla) recruited

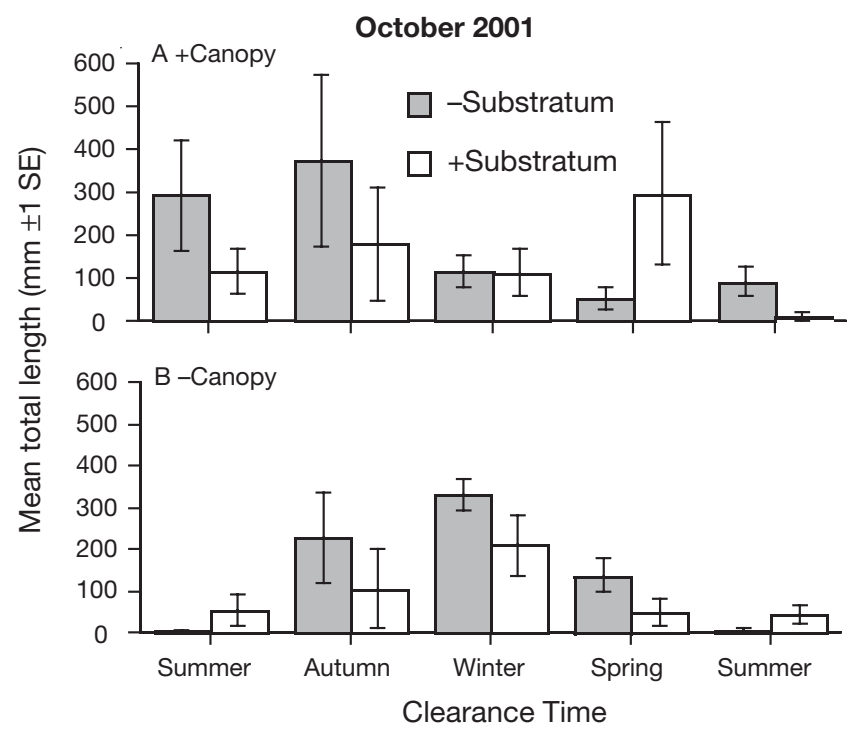

Fig. 5. Durvillaea antarctica. Mean total length of recruits across +/- substratum coralline algae treatments in (A) canopy-intact treatments and (B) canopy-removal treatments within the 5 clearance times in October 2001

during the experiment, and none of them survived for more that a few months. However, there was considerable recruitment and great variation in the cover of foliose red, green and brown algae across clearance times, treatments and sites (Fig. 6). In most cases, these small, non-coralline species recruited within a few months, particularly where substratum clearances were performed and regardless of whether or not the Durvillaea canopy was intact. This was particularly pronounced at Moeraki after the first 3 initiation times (Fig. 6A-C). An exception was the autumn 1999 treatments at Kaikoura, which had poor recruitment of foliose algae (Fig. 6G). By the end of the experiment (October 2001), however, the substratum effects were no longer evident and the treatments outside of the intact Durvillaea canopy had the greatest cover of algae for 3 of the 5 treatment times (Table 4). Generally, few algae recruited into controls, where the canopy and substratum were left intact.

There were differences in the mixtures of species at the 2 sites. At Kaikoura, the most frequent species were brown algae Halopteris congesta, Carpophyllum maschalocarpum and the ephemeral Scytosiphon lomentaria, and the red alga Gelidium caulacantheum. At Moeraki, there were occasionally recruits of Macrocystis pyrifera, Cystophora torulosa, Hormosira banksii and Halopteris congesta. In treatments where canopies were removed and the coralline algae were left intact on the substratum, the most common species were the red algae Lophothamnion hirtum and Ballia callitricha, and the brown Glossophora kunthii. 
Table 4. ANOVA results for percent cover of other foliose algae, turfing coralline and encrusting coralline algae at the end of the experiment in October 2001 with Site, Season cleared (Sn), Canopy (Can) and Substratum (Sub) as factors. Significance levels: ${ }^{*} \mathrm{p}=0.05 ;{ }^{* *} \mathrm{p}=0.01 ;{ }^{* * *} \mathrm{p}=0.001$. a: arcsin square-root-transformed data; $\mathrm{b}$ : $\log (\mathrm{n}+1)$-transformed data. Bold indicates significant effects. All Cochran's tests were not significant

\begin{tabular}{|c|c|c|c|c|c|c|c|}
\hline \multirow[b]{2}{*}{ Source } & \multicolumn{3}{|c|}{ Other foliose algae $\mathrm{e}^{\mathrm{a}}$} & \multicolumn{2}{|c|}{ Turfing coralline algae $\mathrm{e}^{\mathrm{a}}$} & \multicolumn{2}{|c|}{ Encrusting coralline algae } \\
\hline & $\mathrm{df}$ & MS & $F$ & MS & $F$ & MS & $F$ \\
\hline Site & 1 & 4.17 & 3.52 & 1.46 & $25.01^{* * *}$ & 1.58 & $34.37^{* * *}$ \\
\hline Season cleared & 4 & 2.90 & 2.82 & 0.59 & 2.42 & 0.27 & 0.93 \\
\hline Canopy & 1 & 85.12 & $220.22^{*}$ & 1.21 & 2.32 & 5.13 & 10.90 \\
\hline Substratum & 1 & 3.75 & 0.27 & 0.55 & 0.86 & 0.04 & 0.15 \\
\hline Site $\times$ Sn & 4 & 1.03 & 0.87 & 0.24 & $4.17^{* *}$ & 0.29 & $6.24^{* * *}$ \\
\hline Site $\times$ Can & 1 & 0.39 & 0.33 & 0.52 & $8.94^{* *}$ & 0.47 & $10.24^{* *}$ \\
\hline $\mathrm{Sn} \times \mathrm{Can}$ & 4 & 3.59 & 4.41 & 0.19 & 1.28 & 0.08 & 2.18 \\
\hline Site $\times$ Sub & 1 & 14.13 & $11.95^{* * *}$ & 0.63 & $10.87^{* *}$ & 0.30 & $6.44^{*}$ \\
\hline $\mathrm{Sn} \times \mathrm{Sub}$ & 4 & 0.52 & 0.38 & 0.38 & 4.37 & 0.14 & 4.85 \\
\hline Can $\times$ Sub & 1 & 0.28 & 0.04 & 0.93 & 112.45 & 0.05 & 1.10 \\
\hline Site $\times$ Sn $\times$ Can & 4 & 0.81 & 0.69 & 0.14 & $2.48^{*}$ & 0.04 & 0.80 \\
\hline Site $\times$ Sn $\times$ Sub & 4 & 1.39 & 1.17 & 0.09 & 1.50 & 0.03 & 0.62 \\
\hline Site $\times$ Can $\times$ Sub & 1 & 7.37 & $6.23^{*}$ & 0.01 & 0.14 & 0.05 & 1.00 \\
\hline $\mathrm{Sn} \times \mathrm{Can} \times \mathrm{Sub}$ & 4 & 0.70 & 0.43 & 0.02 & 0.68 & 0.08 & 2.91 \\
\hline Site $\times$ Sn $\times$ Can $\times$ Sub & 4 & 1.62 & 1.37 & 0.02 & 0.38 & 0.03 & 0.62 \\
\hline Error & & 120 & 1.18 & & 0.06 & & 0.05 \\
\hline
\end{tabular}

\section{Turfing coralline algae}

The cover of turfing coralline algae (Corallina officinalis, Jania spp., Haliptilon roseum) generally recovered slowly after initial substratum clearances, although this tended to vary between sites (Fig. 7, Table 4). Moeraki had a greater initial cover of turfing coralline algae ranging from 30 to $60 \%$, compared to $<20 \%$ at Kaikoura. Where the canopy was cleared (-Can -Sub), the turfing corallines grew back within several months. In all cases at Moeraki, the greatest cover at the end of the experiment occurred in the treatments where Durvillaea canopies were removed but the coralline substratum was left intact. At Kaikoura, however, the results were far more variable. Generally, the recovery of turfing corallines did not depend on the presence or absence of an intact $D$. antarctica canopy, but several canopy removal treatments had increased cover of turfing corallines by the end of the experiment. By October 2001, the substratum treatments were still readily discerned at Moeraki but not at Kaikoura, where the overall cover was less.

\section{Encrusting coralline algae}

Encrusting coralline Lithothamnion spp. recovered slowly after the initial substratum clearances although, again, this varied between sites and clearance times (Fig. 8, Table 4). Generally, Kaikoura had a greater initial cover of encrusting coralline algae ranging from 70 to $90 \%$, compared to 45 to $80 \%$ at
Moeraki. In all clearances, the removal of the Durvillaea canopy resulted in a decrease in encrusting coralline algae (Fig. 7A-J). Encrusting corallines generally recovered best in the treatment where the Durvillaea canopy was left intact. Where the adult canopy was removed, there was an initial burn-off of the exposed corallines. The later decrease seen in many treatments was due to the expansion of turfing corallines. There was poor recovery in the treatments initiated in summer 1999/2000.

\section{DISCUSSION}

The ability of Durvillaea antarctica to recruit beneath adult canopies has important implications for its self-replacement capabilities and the structure of understorey communities. Few other large brown algae and no filter-feeding assemblages recruited into any of the treatments, despite spanning the reproductive and settlement periods of all species. The effects of underlying coralline algae were complex but over time, across treatments, there was a strong negative effect of these species on recruitment. Due to its relatively discrete reproductive period, the time of clearance affected the ability of $D$. antarctica to successfully re-capture space. Initial recruitment was greatest in winter treatments when $D$. antarctica is reproductive. These results have important implications for understanding the recovery of populations of this habitatforming alga following natural disturbances and harvesting. 


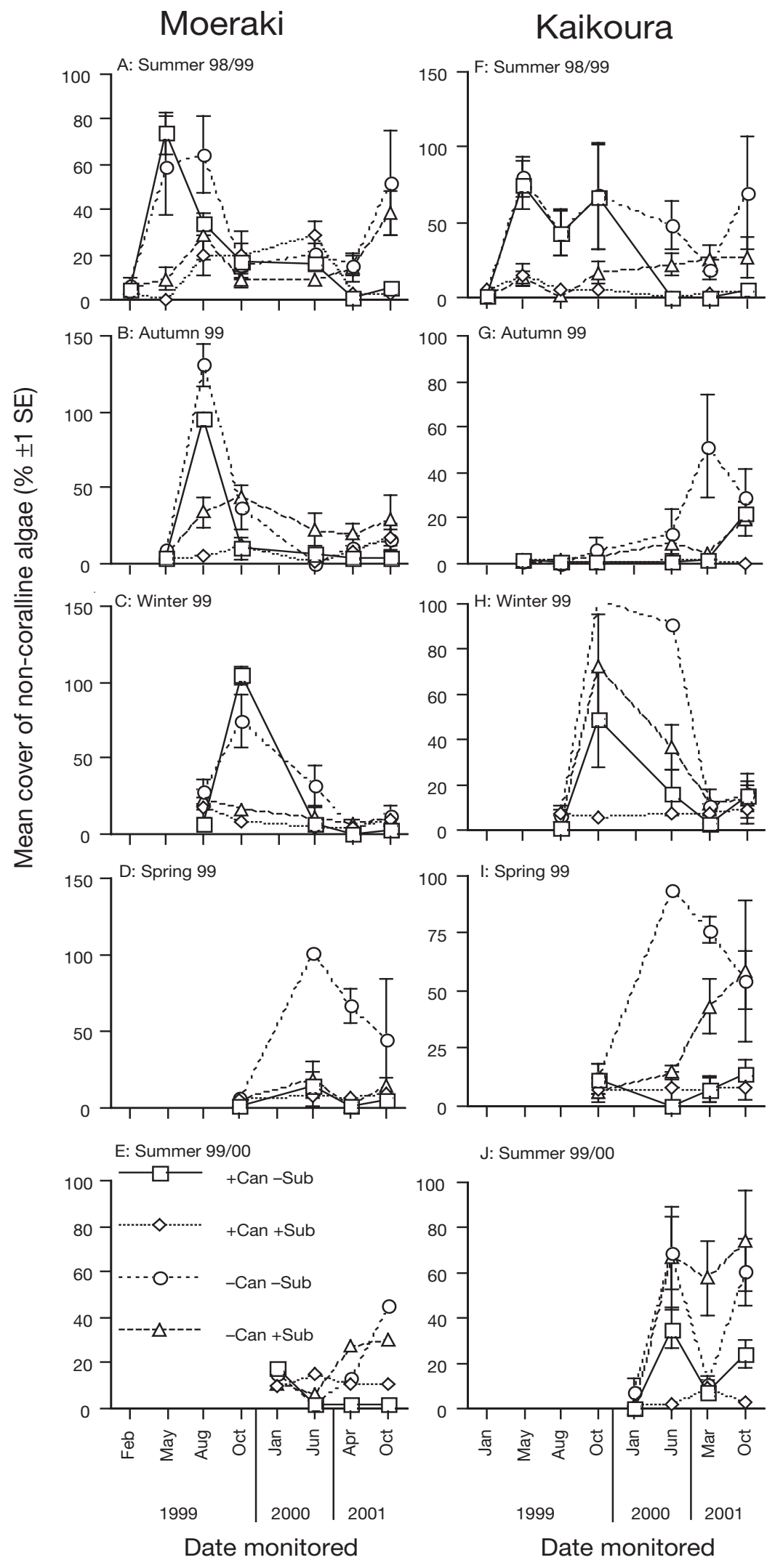

Fig. 6. Mean cover of all noncoralline algae per $0.09 \mathrm{~m}^{2}( \pm 1 \mathrm{SE})$ (includes all other foliose brown, red and green algae) at each sampling time at the 5 initiation times in summer 1998 (A,F), autumn 1999 (B,G), winter 1999 (C,H), spring 1999 (D,I) and summer $1999(\mathrm{E}, \mathrm{J})$ at Moeraki and Kaikoura 


\section{Moeraki}
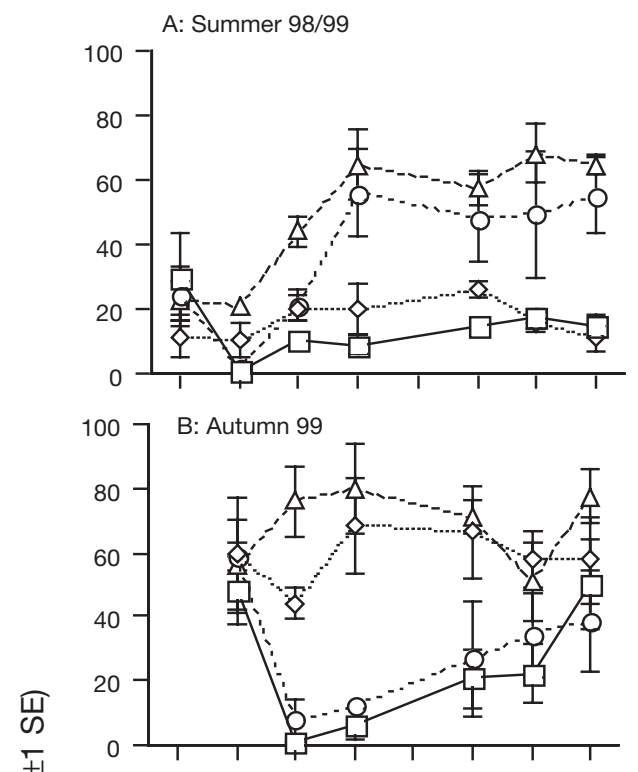

¿ $100-$ C: Winter 99

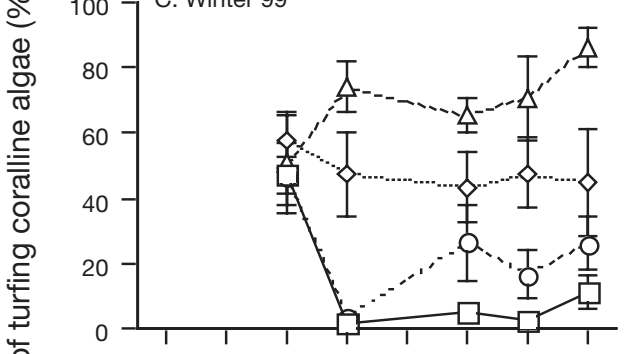

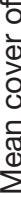
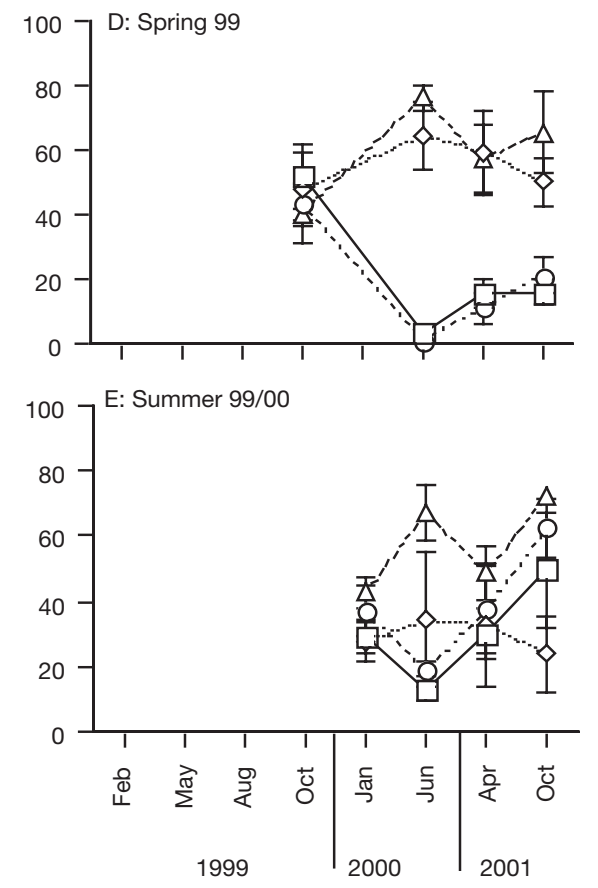

Date monitored

\section{Kaikoura}
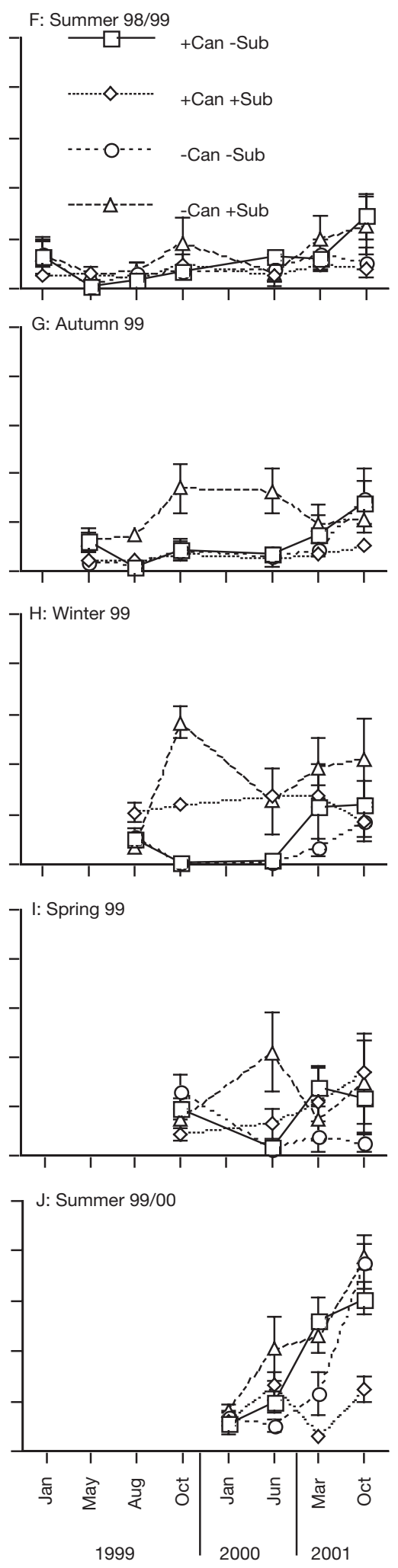

Date monitored

Fig. 7. Mean percent cover of all turfing coralline algae $( \pm 1 \mathrm{SE})$ at each sampling time at the 5 initiation times in summer 1998 $(\mathrm{A}, \mathrm{F})$, autumn $1999(\mathrm{~B}, \mathrm{G})$, winter $1999(\mathrm{C}, \mathrm{H})$, spring $1999(\mathrm{D}, \mathrm{I})$ and summer $1999(\mathrm{E}, \mathrm{J})$ at Moeraki and Kaikoura 
Moeraki

Kaikoura

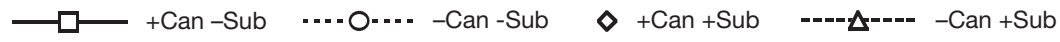
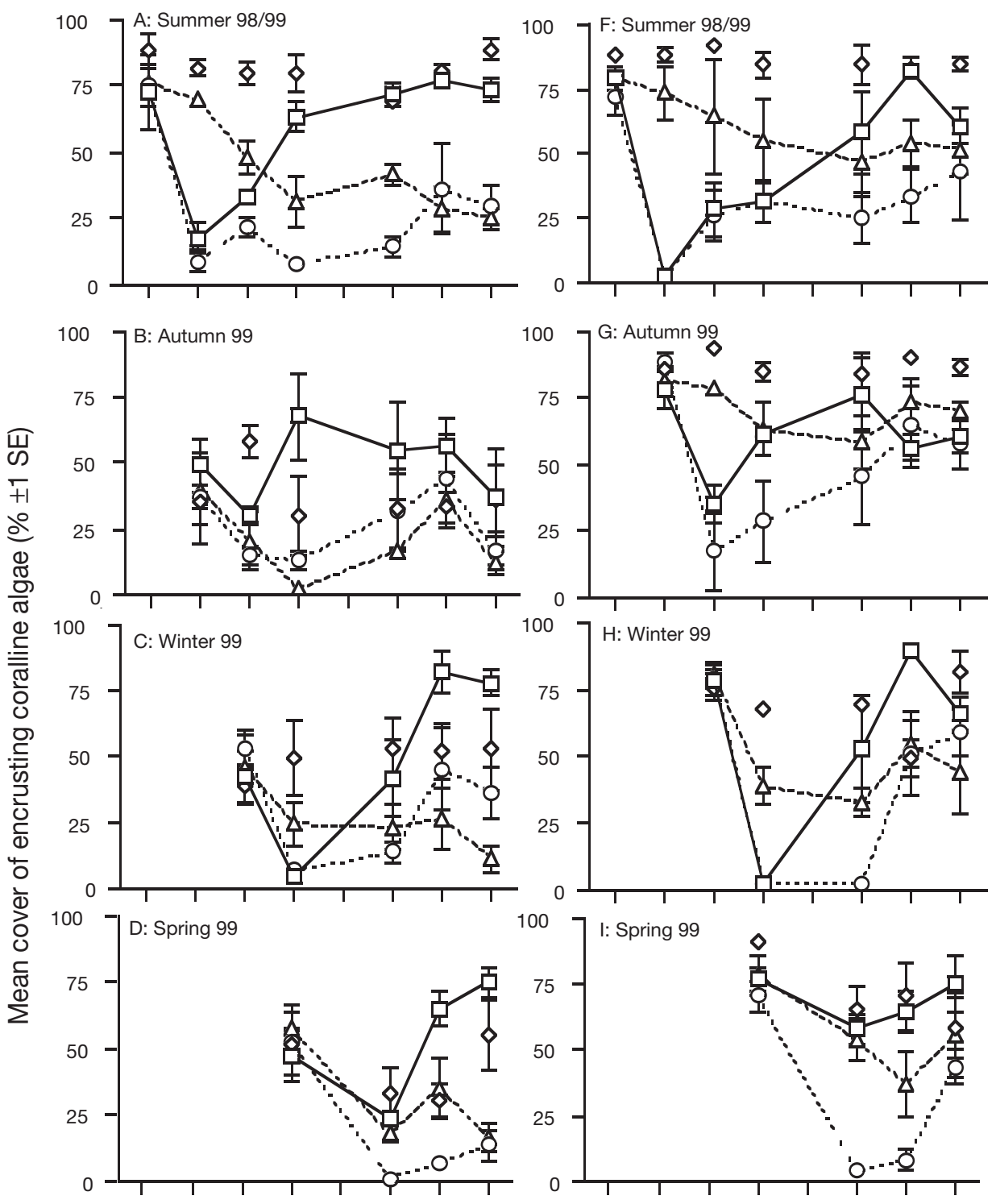

1007 G: Autumn 99

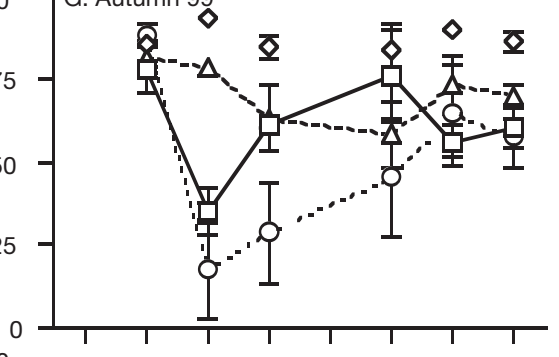

7 H: Winter 99
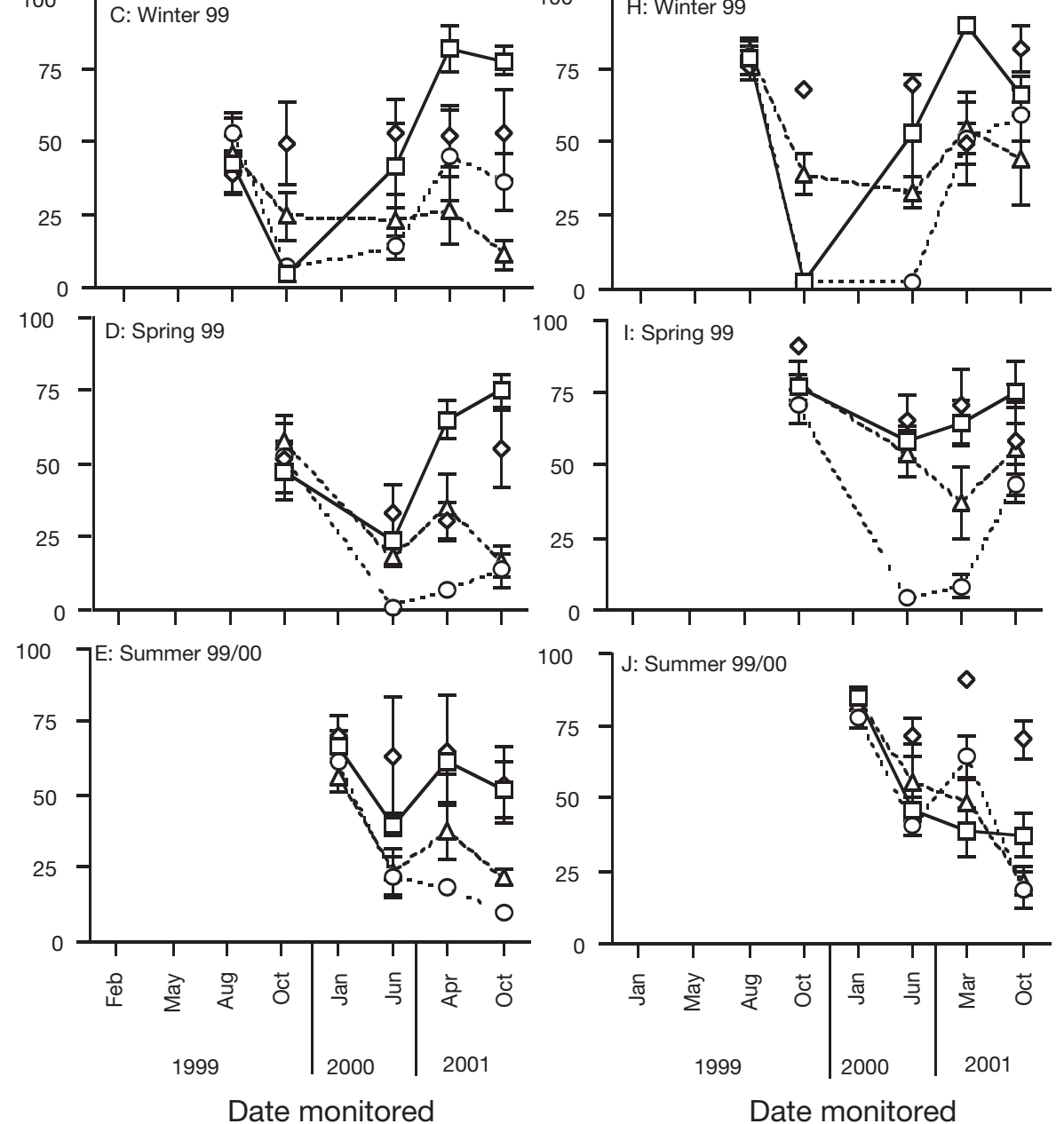

Fig. 8. Mean percent cover of encrusting coralline algae $( \pm 1 \mathrm{SE})$ at each sampling time at the 5 initiation times in summer 1998 (A,F), autumn $1999(\mathrm{~B}, \mathrm{G})$, winter $1999(\mathrm{C}, \mathrm{H})$, spring $1999(\mathrm{D}, \mathrm{I})$ and summer $1999(\mathrm{E}, \mathrm{J})$ at Moeraki and Kaikoura 


\section{Intra-specific interactions}

The process of self-replacement varies between species of large brown algae (Chapman 1986, Schiel 1988, Santelices 1990b). A common feature of this ecologically important process is a tendency for greatest recruitment to occur immediately outside adult canopies. Surprisingly, we found that Durvillaea antarctica recruitment can occur directly under adult canopies, particularly if coralline algae were removed. However, there were differences between sites in the canopy and substratum effects. Between-site differences in substratum heterogeneity and rock type may have been responsible for these differences. The broken mudstone reef at Kaikoura may have provided more opportunities for recruits to survive outside adult canopies despite fish grazing effects.

That Durvillaea antarctica recruitment occurred under adult canopies is contrary to many studies of large brown algae but, in this high-energy environment, it may be an effective strategy for self-replacement outside usual recruitment times. In central Chile, recruitment has been stated to occur all year round (Santelices et al. 1980, Santelices 1990a,b). It is possible that these observations resulted from small fugitive recruits from beneath adult canopies remaining when canopies were removed by storms. As adult plants are frequently removed by storm events (Hay 1977, Santelices et al. 1980), the presence of small fugitive recruits under canopies could ensure immediate recovery of populations despite reproduction only occurring in discrete periods.

The overall poor growth and survival under canopies, however, suggests the habitat is suboptimal for recruitment. In the subtidal zone, factors such as shading, and possibly nutrient depletion, have been shown to inhibit intra- and interspecific recruitment under adult canopies (Kennelly 1983, 1987 Dayton et al. 1984, Reed \& Foster 1984, Schiel 1988, Clark et al. 2004). However, the canopy effects on algal recruitment vary with species and some large brown algae are capable of recruiting into low-light, sub-canopy habitats (Clark et al. 2004). Schiel (1981), for example, found that the subtidal fucoid Landsburgia quercifolia (Hooker et Harvey) Harvey was able to recruit under adult canopies of Ecklonia radiata (C. Agardh) in NE New Zealand.

Rather than any particular facility to withstand lowlight situations, the ability of Durvillaea antarctica to recruit under canopies is probably related to interholdfast distances and escapes from whiplash effects of adult canopies (cf. Santelices \& Ojeda 1984). Sweeping and whiplash effects of adult canopies can greatly affect recruitment of large brown algae in the turbulent intertidal environment (Santelices \& Ojeda 1984).
In central Chile, Santelices \& Ojeda (1984) showed that recruitment of the large brown alga Lessonia nigrescens was most likely to occur in an optimal canopy gap size large enough to reduce the sweeping and whiplash effects of adults, but small enough to prevent grazing by sea urchins. In the case of Durvillaea antarctica, the erect stipe of adults may elevate the blades enough to allow an area close to the holdfast where whiplash effects may not be so great.

\section{Interspecific interactions}

In general, recruitment of Durvillaea antarctica was greater in treatments where understorey coralline algae had been removed, regardless of canopy treatment. The relationship between recruitment of large perennial algae and coralline algae can be complex and variable. Encrusting coralline algae appear to inhibit recruitment of other algae through sloughing of epithallial cells (Johnson \& Mann 1986, Vadas et al. 1992, Camus 1994). For example, Camus (1994) suggested that, through the shedding of epithallial cells, encrusting corallines reduced the recruitment of Lessonia nigrescens in central Chile. In another example, Worm \& Chapman (1996) found that the recruitment of Fucus evanescens was inhibited by the crustose alga Chondrus crispus Stackhouse that prevented successful attachment of young plants. However, turfing coralline algae have been shown to facilitate the recruitment of several species of fucoid algae (Brawley \& Johnson 1991, 1993, Benedetti-Cecchi \& Cinelli 1992). For example, using agarose beads, Brawley \& Johnson (1991) found that the microhabitat provided by turfing corallines provided protection from desiccation for zygotes of Pelvetia fastigiata.

Turfing coralline algae are often among the first species to colonise disturbed areas in lower intertidal zones (Hay 1981, Menge et al. 1993). At both Moeraki and Kaikoura, cover of turfing corallines increased once Durvillaea antarctica canopies were removed, probably due to a reduction in whiplash effects. Other studies have shown that macroalgal canopies can maintain and facilitate encrusting coralline habitat, while inhibiting turfing coralline algae (Connell 2003a,b). For example, in a recent study in south Australia, Melville \& Connell (2001), using reciprocal transplants of turf and encrusting coralline boulders, found that Ecklonia radiata canopies, rather than simply co-occurring with encrusting coralline algae, actually facilitated its growth and survival by inhibiting turfing coralline algae.

Few other species of large brown algae recruited into canopy removal treatments and those that did, disappeared soon after recruitment of Durvillaea antarc- 
tica. Recruitment of algae into disturbed intertidal areas is largely determined by clearance time, size of clearance, grazing, the dispersal and reproductive characteristics of the algal species and growth (Paine 1984, Sousa 1984, Schiel 1988, Farrell 1989, Menge et al. 1993, Kim \& DeWreede 1996, McCook \& Chapman 1997). We found that other species of foliose algae were more likely to recruit into treatments in which D. antarctica canopies had been removed and were initiated outside the winter reproductive period of D. antarctica.

The recruitment of other algae into canopy clearance areas was closely related to the proximity of other algal habitats and may be related to the dispersal abilities of surrounding species. The fucoid algae that surround Durvillaea habitats are relatively poor dispersers due to their relatively large egg sizes (Clayton 1990, 1992, Chapman 1995). Consequently, zygotes rarely settle more than a few meters from adult plants (D.I.T. unpubl. data). Moreover, the ability of fucoid species to stick quickly and remain attached in wave-exposed situations can vary between species. For example, Taylor \& Schiel (2003) found that the fucoid algae Cystophora torulosa and Hormosira banksii took longer to attach and had poorer survival across wave exposures than $D$. antarctica.

At Moeraki, large beds of Cystophora torulosa, Hormosira banksii and Xiphophora chondrophylla on the periphery of the Durvillaea antarctica habitat resulted in the recruitment of small plants of these species into turf-covered canopy clearance treatments, which disappeared quickly as D. antarctica recruited. At Kaikoura, other species such as Carpophyllum maschalocarpum and Halopteris congesta were more abundant on the edge of $D$. antarctica canopies, and a small number of plants recruited into the same treatments but eventually disappeared following recruitment of $D$. antarctica.

Ephemeral algae and diatomaceous films were the first species to colonise coralline removal treatments. In this study, no immediate effects of ephemeral algae on the recruitment of Durvillaea antarctica were found. Hay (1979) documented similar results in a limpet removal experiment in Kaikoura. He found $D$. antarctica quickly recruited into areas dominated by ephemeral algae if limpets were removed during the D. antarcticas reproductive season, even though limpet removals were above the usual distribution of D. antarctica. These results are in contrast to those of several studies of algal succession in the higher intertidal zone where recruitment of fucoid algae is often suppressed by ephemeral algae, slowing succession (Lubchenco \& Menge 1978, Underwood \& Jernakoff 1981, Hawkins \& Hartnoll 1983, Cubit 1984, Kim 1997). For example, Kim (1997) found recruitment of Fucus gardneri Silva, in the upper intertidal zone in British Columbia, was slowed when limpet grazers were excluded and a cover of ephemeral algae dominated.

The effects of invertebrate grazers that inhabit Durvillaea antarctica holdfasts and geniculate coralline assemblages were not examined in this study. Molluscan grazers are abundant under D. antarctica holdfasts. For example, Edgar \& Burton (2000) found 23 macro-invertebrate taxa, many of which were herbivorous limpets and chitons, under holdfasts on the subantarctic Heard Island off Australia. An alternative explanation for the lack of recruitment of other species of large brown algae into treatments could be that such grazers selectively removed these species. Furthermore, it is also possible that a release from grazing by the suites of micro-grazers that inhabit turfing coralline assemblages (Duffy \& Hay 2000), might also explain the greater recruitment of $D$. antarctica into coralline removal treatments and possibly some of the between-site differences.

We observed that post-recruitment mortality of Durvillaea antarctica was greatly affected by the grazing effects of the herbivorous fish Odax pullus. In some cases, D. antarctica canopies appeared to afford some protection from fish grazing and possibly desiccation, but in most treatments, the great number of recruits ensured that 1 or 2 plants reached what appeared to be a size refuge from grazing.

Many Durvillaea antarctica recruits from outside adult canopies had some evidence of fish grazing (lunate bite marks along the margin of the lamina) and plants were regularly grazed back to stipes. This resulted, in most cases, in the eventual death of the recruits (D.I.T. pers. obs.). In some cases, plants regrew from the remaining blade on the margin of the fish bite marks. Hay (1977) also documented similar growth patterns of Durvillaea recruits from Otago and Kaikoura in southern New Zealand following butterfish grazing. In their example of harvesting effects, Hay \& South (1981) showed that if fronds were pruned above the holdfast, plants recovered to only $32 \%$ of pre-harvest biomass after 15 mo. However, in central Chile, Santelices et al. (1980) found that D. antarctica lacked the ability to regenerate from storm-damaged stipes.

While there are several examples of invertebrate grazers controlling algal abundance in the lower tidal zones (Sousa et al. 1981, Choat \& Schiel 1982, Andrew \& Underwood 1989, Jones \& Andrew 1990, Andrew 1993), there are very few examples of herbivorous fish controlling the abundance of intertidal algae in temperate climates. The majority of examples are from subtidal studies. For example, in the Mediterranean sublittoral, Sala \& Boudouresque (1997) found that experimental reduction of fish grazing led to dramatic 
changes in algal community structure, with significant increases in the abundance of fleshy erect algae. In Ecklonia radiata forests in New South Wales, Andrew \& Jones (1990) describe the formation of patches by Odax cyanomelas. They found that, during spring, adult female O. cyanomelas cleared patches of adult Ecklonia near territorial males creating single age cohorts in patches. This is in contrast to the effects of Odax pullus in our study, where grazing occurred all year round during calm periods and mainly on recruit stages.

In general, examples of fishes controlling intertidal algal abundance are not common in the literature. However, Ojeda \& Munoz (1999) provided an experimental example of fish grazing determining algal abundance in a temperate intertidal environment on the coast of central Chile. Their results show that grazing by the herbivorous fish Scartichthys viridis had significant effects on the algal community structure in the mid-intertidal zone by reducing the cover of the green alga Ulva rigida and the red alga Gelidium chilense. No examples of fish controlling intertidal brown algae abundance could be found in the literature.

\section{Summary}

Overall, Durvillaea antarctica appears to dominate these highly disturbed environments by arriving and recruiting in great numbers near adult canopies. We found that this is most likely to occur when free space occurs during winter and, because of winter storms, this is the time when free space is most readily available. The whiplash effects of $D$. antarctica canopies appears to modify the understorey community by suppressing understorey turfing coralline algae and excluding all other species of large brown algae.

Acknowledgements. We thank the Foundation for Research, Science and Technology, the Andrew Mellon Foundation and NIWA (The National Institute for Water and Atmospheric Research) for support of this research. We also thank 3 anonymous reviewers for their constructive comments. As always, the Marine Ecology Research Group provided invaluable field assistance, camaraderie and constructive criticism.

\section{LITERATURE CITED}

Andrew NL (1993) Spatial heterogeneity, sea urchin grazing, and habitat structure on reefs in temperate Australia. Ecology 74:292-302

Andrew NL, Jones GP (1990) Patch formation by herbivorous fish in a temperate Australian kelp forest. Oecologia 85: $57-68$

Andrew NL, Underwood AJ (1989) Patterns of abundance of the sea urchin Centrostephanus rodgersii (Agassiz) on the central coast of New South Wales, Australia. J Exp Mar Biol Ecol 131:61-80
Benedetti-Cecchi L, Cinelli F (1992) Effects of canopy cover, herbivores and substratum type on patterns of Cystoseira spp. settlement and recruitment in littoral rockpools. Mar Ecol Prog Ser 90:183-191

Brawley SH, Johnson LE (1991) Survival of fucoid embryos in the intertidal zone depends upon developmental stage and microhabitat. J Phycol 27:179-186

Brawley SH, Johnson LE (1993) Predicting dessication stress in microscopic organisms: the use of agarose beads to determine evaporation within and between intertidal microhabitats. J Phycol 29:528-535

Camus P (1994) Recruitment of the intertidal kelp Lessonia nigrescens Bory in northern Chile: successional constraints and opportunities. J Exp Mar Biol Ecol 184: 171-181

Chapman ARO (1986) Population and community ecology of seaweeds. Adv Mar Biol 23:1-161

Chapman ARO (1995) Functional ecology of fucoid algae: twenty-three years of progress. Phycologia 34:1-32

Choat JH, Schiel DR (1982) Patterns of distribution and abundance of large brown algae and invertebrate herbivores in subtidal regions of northern New Zealand. J Exp Mar Biol Ecol 60:129-162

Clark RP, Edwards MS, Foster MS (2004) Effects of shade from multiple kelp canopies on an understorey algal assemblage. Mar Ecol Prog Ser 267:107-119

Clayton MN (1990) The adaptive significance of life history characters in selected orders of marine brown macroalgae. Aust J Ecol 15:430-452

Clayton MN (1992) Propagules of marine macroalgae: structure and development. Br Phycol J 27:219-232

Connell SD (2003a) The monopolization of understorey habitat by subtidal encrusting coralline algae: a test of the combined effects of canopy-mediated light and sedimentation. Mar Biol 142:1065-1071

Connell SD (2003b) Negative effects overpower the positive of kelp to exclude invertebrates from the understorey. Oecologia 137:97-103

Cubit JD (1984) Herbivory and the seasonal abundance of algae on a high intertidal rocky shore. Ecology 65: 1904-1917

Dayton PK, Currie V, Gerrodette T, Keller BD, Rosenthal R, Ven Tresca D (1984) Patch dynamics and stability of some Californian kelp communities. Ecol Monogr 54:253-289

Duffy JE, Hay ME (2000) Strong impacts of grazing amphipods on the organization of a benthic community. Ecol Monogr 70:237-263

Edgar GJ, Burton HR (2000) The biogeography of shallowwater macrofauna at Heard Island. Pap Proc R Soc Tasman 133:23-26

Farrell TM (1989) Succession in a rocky intertidal community: the importance of disturbance size and position within a disturbed patch. J Exp Mar Biol Ecol 128:57-73

Foster MS, Schiel DR (1987) Kelp communities and sea otters: keystone species of just another brick in the wall? Ecol Stud 65:247

Hawkins SJ, Hartnoll RG (1983) Grazing of intertidal algae by marine invertebrates. Oceanogr Mar Biol Annu Rev 21: 195-282

Hay CH (1977) A biological study of Durvillaea antarctica (Chamisso) Hariot and D. willana Lindauer in New Zealand. University of Canterbury, Christchurch

Hay CH (1979) Some factors affecting the upper limit of the southern bull kelp Durvillaea antarctica (Chamisso) Hariot on 2 New Zealand shores. J R Soc NZ 9:279-289

Hay CH, South GR (1979) Experimental ecology with particular reference to proposed commercial harvesting of 
Durvillaea (Phaeophyta, Durvilleales) in New Zealand. Bot Mar 22:431-436

Hay CH, South GR (1981) Some implications of field experiments on proposed commercial harvesting of Durvillaea in New Zealand. Proc Int Seaweed Symp 8:699-712

Hay ME (1981) The functional morphology of turf-forming seaweeds: persistence in stressful marine habitats. Ecology 61:739-750

Hurd CL (2000) Water motion, marine macroalgal physiology, and production. J Phycol 36:453-472

Johnson CR, Mann KH (1986) The crustose coralline alga, Phymatolithon foslie, inhibits the overgrowth of seaweeds without relying on herbivores. J Exp Mar Biol Ecol 96: $127-146$

Jones GP, Andrew NL (1990) Herbivory and patch dynamics on rocky reefs in temperate Australasia: the roles of fish and sea urchins. Aust J Ecol 15:505-520

Kennelly SJ (1983) An experimental approach to the study of factors affecting algal colonization in a sublittoral kelp forest. J Exp Mar Biol Ecol 68:257-276

Kennelly SJ (1987) Inhibition of kelp recruitment by turfing algae and consequences for an Australian kelp community. J Exp Mar Biol Ecol 112:49-60

Kim JH (1997) The role of herbivory, and direct and indirect interactions, in algal succession. J Exp Mar Biol Ecol 217: 119-135

Kim JH, DeWreede RE (1996) Effects of size and season of disturbance on algal patch recovery in a rocky intertidal community. Mar Ecol Prog Ser 133:217-228

Lubchenco J, Menge BA (1978) Community development and persistence in a low rocky intertidal zone. Ecol Monogr 48: 67-94

McCook LJ, Chapman ARO (1997) Patterns and variations in natural succession following massive ice-scour of a rocky intertidal seashore. J Exp Mar Biol Ecol 214:121-147

Melville AJ, Connell SD (2001) Experimental effects of kelp canopies on subtidal coralline algae. Aust Ecol 26:102-108

Menge BA, Branch GM (2001) Rocky intertidal communities. In: Bertness MD, Gaines SD, Hay M (eds) Marine community ecology. Sinauer Associates, Sunderland, MA, p 221-251

Menge BA, Farrell TM, Olson AM, Tamelen Pv, Turner T (1993) Algal recruitment and the maintenance of a plant mosaic in the low intertidal region on the Oregon coast. J Exp Mar Biol Ecol 170:91-116

Menge BA, Daley BA, Wheeler PA, Dahlhoff E, Sanford E, Strub PT (1997) Benthic-pelagic links and rocky intertidal communities: bottom-up effects on top-down control? Proc Natl Acad Sci USA 94:14530-14535

Naylor M (1953) The New Zealand species of Durvillaea. Trans R Soc NZ 80:277-297

Nelson WA (1994) Distribution of macroalgae in New Zealand: an archipelago in space and time. Bot Mar 37:221-233

Ojeda FP, Munoz AA (1999) Feeding selectivity of the herbivorous fish Scartichthys viridis: effects on macroalgal community structure in a temperate rocky intertidal coastal zone. Mar Ecol Prog Ser 28:219-229

Paine RT (1984) Ecological determinism in the competition for space. Ecology 65:1339-1348

Reed DC, Foster MS (1984) The effects of canopy shading on algal recruitment and growth in a giant kelp forest. Ecology 65:937-948
Sala E, Boudouresque CF (1997) The role of fishes in the organization of a Mediterranean sublittoral community. I: Algal communities. J Exp Mar Biol Ecol 212:25-44

Santelices B (1990a) Patterns of organizations of intertidal and shallow subtidal vegetation in wave exposed habitats of central Chile. Hydrobiologia 192:35-57

Santelices B (1990b) Patterns of reproduction, dispersal and recruitment in seaweeds. Oceanogr Mar Biol Annu Rev 28:177-276

Santelices B, Ojeda FP (1984) Recruitment, growth and survival of Lessonia nigrescens (Phaeophyta) at various tidal levels in exposed habitats of central Chile. Mar Ecol Prog Ser 19:73-82

Santelices B, Castilla JC, Cancino J, Schmiede P (1980) Comparative ecology of Lessonia nigrescens and Durvillaea antarctica (Phaeophyta) in central Chile. Mar Biol 59: 119-132

Schiel DR (1981) A demographic and experimental evaluation of plant and herbivore interactions in subtidal algal stands. PhD thesis, University of Auckland

Schiel DR (1988) Algal interactions on shallow subtidal reefs in Northern New Zealand: a review. NZ J Mar Freshw Res 22:481-489

Schiel DR (1990) Macroalgal assemblages in New Zealand: structure, interactions and demography. Hydrobiologia 192:59-76

Schiel DR, Foster MS (1986) The structure of subtidal algal stands in temperate waters. Oceanogr Mar Biol Annu Rev 24:265-307

Schiel DR, Taylor DI (1999) Effects of trampling on a rocky intertidal algal assemblage in southern New Zealand. J Exp Mar Biol Ecol 235:213-235

Schiel DR, Andrew NL, Foster MS (1995) The structure of subtidal algal and invertebrate assemblages at the Chatham Islands, New Zealand. Mar Biol 123:355-367

Schonbeck M, Norton TA (1978) Factors controlling the upper limits of fucoid algae on the shore. J Exp Mar Biol Ecol 31: 303-313

Sousa WP (1984) Intertidal mosaics: patch size, propagule availability and spatially variable patterns of succession. Ecology 65:1918-1935

Sousa WP, Schroeter SC, Gaines SD (1981) Latitudinal variation in intertidal algal community structure: the influence of grazing and vegetative propagation. Oecologia 48: 297-307

Stephenson TA, Stephenson A (1972) Life between the tidemarks on rocky shores. WH Freeman, San Francisco, CA

Taylor DI, Schiel DR (2003) Wave-related mortality in zygotes of habitat-forming algae from different exposures in southern New Zealand: the importance of 'stickability'. J Exp Mar Biol Ecol 290:229-245

Underwood AJ, Jernakoff P (1981) Effects of interactions between algae and grazing gastropods on the structure of a low-shore intertidal algal community. Oecologia 48: 221-233

Vadas SRL, Johnson S, Norton TA (1992) Recruitment and mortality of early post-settlement stages of benthic algae. Br Phycol J 27:331-351

Worm B, Chapman ARO (1996) Interference competition among two intertidal seaweeds: Chondrus crispus strongly affects survival of Fucus evanescens recruits. Mar Ecol Prog Ser 145:297-301

Submitted: September 15, 2004; Accepted: October 19, 2004 Proofs received from author: February 23, 2005 